\title{
Research on the Mediating Effect of Corporate Governance Behavior Between GEM and Governance Performance of Listed Companies on the Growth Enterprise
}

\author{
Wenming Sun, Anhui Open University, China \\ Leilei Jiang, Anhui Open University, China \\ Ke Dong, Anhui Open University, China
}

\begin{abstract}
At the end of 2019, the sudden attack of the COVID-19 brought huge challenges to the management, operation, and development of listed companies. In view of the suddenness of the epidemic, the internal governance of listed companies is even more important! With governance structure and performance and structure and behavior affected by the behavior of the index system, the 20192020 China GEM-listed companies as a sample of equity concentration, the human capital board of directors as the sample explanatory variable, business performance and innovation performance as dependent variables, and supervision and behavior as intermediaries to encourage behavior, related test hypotheses verify the path that Chinese companies listed in the GEM governance structure affect governance performance through behavior.
\end{abstract}

\section{KEYWORDS}

COVID-19, Governance, Governance Behavior, Governance Structure

\section{INTRODUCTION}

Facing the competition of economic globalization, China's modern enterprise system starts later than the European and American countries, and China's market mechanism is not mature enough, which puts forward a severe test to the development of Chinese enterprises (Bai et al., 2005). Therefore, it is urgent for Chinese enterprises to have good performance and sustainable development level, so as to improve their competitiveness in the international market. Based on this background, China introduced the theory of corporate governance at the end of the 20th century, hoping to guide Chinese enterprises to enhance their comprehensive competitiveness (Ping \& Hai, 2012; Wei \& Xiling, 2010). The theory of corporate governance has been put forward and developed from the initial research perspective focusing on the micro level of corporate performance, gradually rising to the macro level of capital market and financial system, which has an immeasurable impact on modern enterprises, and has been widely valued by academia, practitioners and even governments of all countries. A complete performance management system should include performance management system, key performance indicator (KPI) system, daily performance standards for each position and performance management process. Among them, the most often neglected one is the daily performance standard of each position. It refers to the assessment standard established for the work items (repeated work 
behaviors) of each job, and its key role is that it is an important supplement to KPI assessment (Ping, 2006). Although the research path and paradigm of this theory are different, so it has many branches, which just shows the degree of attention and objectivity of this theory. After decades of continuous improvement, it has become a relatively mature and developing theory. The development of corporate governance theory is like a towering tree, which has a hard trunk, rich branches, dense leaves, and is still growing healthily (Feng \& Sun, 2014).

In the international community, the research on the impact of corporate governance performance on corporate value has achieved rich results, and the research methods are increasingly mature. China's reform and opening-up in the 1980s has brought China closer to the integration of the world (Hanxianglujin, 2012; Shahri et al., 2019). Especially after China's accession to the world trade organization, the corporate governance of China, as a new research sample, has attracted the attention of many European and American scholars, Japan and South Korea. By using various data of Chinese enterprises, scholars empirically analyze whether Chinese enterprises support the corporate governance model based on the European and American markets, Japan and South Korea markets, and carry out a series of related research based on this. The classic research path is the promotion and influence of the enterprise's equity structure on the enterprise value (Pham et al., 2019). However, with the financial crisis erupted in 2008, the academic and practical circles explained in many aspects, such as the low interest rate of the Federal Reserve, the excessive leverage in the US market, and the collapse of many bubble industries (generally believed that the bubble burst in the real estate industry had a direct impact on the economic crisis), but failed to find out the deeper reasons for the outbreak of the economic crisis, or the causes of the outbreak. Some scholars point out that the origin of this crisis is the major investment banks in the United States which have serious deficiencies in corporate governance structure (Qing, 2007).

In short, the development of theory of corporate governance, internal corporate governance is effective, is to determine the robustness of China's economy, the fundamental elements of sustainable development, is a prerequisite for China's modern enterprise system can catch up, but also the healthy growth of Chinese enterprises, in the face international competition and opportunities of economic globalization an important factor. In this perspective, corporate governance research, especially on corporate governance and performance of strategic and practical needs is very important (Li \& Lei, 2001; Weian, 2011).

The purpose of this study is to explore in Chinese companies listed on Growth Enterprises Market (GEM) particular context, the relationship between the two governance structure and performance. By combing the previous literature, scholars who study the path mostly based on "Governance Performance Management Structure $\rightarrow$ " direct logic paradigm, and so empirical research. Despite extensive empirical research does provide a great deal of empirical evidence for the study of the effectiveness of governance arrangements, but "governance structure $\rightarrow$ performance management," the causal chain may not be simple and straightforward, but a neglected between the structure to performance process, you may get less comprehensive conclusion of the study (Weian, 2008; Weian, 2013; Weian et al., 2009; Weian \& Wang, 2007). This study attempts to study in the traditional path, out of "performance management governance structure $\rightarrow$ " direct logic paradigm, drawing on theories of industrial economics SCP (Structure- Conduct-Performance), build a "governance structure $\rightarrow$ $\rightarrow$ governance practices of governance performance" mechanism model, combined with the panel data 2019 - 2020 Chinese companies listed on GEM of hypothetical model empirical research to explore the "black box" issues of governance structure affects governance performance, conducted a little exploration and research in the framework wealth of corporate governance. China GEM listed companies include human resource planning, talent assessment center, training demand research and training operation building design, performance management system design, compensation system design and professional research and other professional work, while helping HRBP to solve the more professional problems in human resource management encountered in business units, and from a professional point of view to help companies to develop and improve We also assist companies in 
formulating and improving HR management regulations from a professional perspective, and guide HRSSC to carry out service activities.

This study defines "innovation" as the company's ability to manage a new dimension of performance indicators, Chinese companies listed on GEM this study sample, contribute to a more scientific measure of treatment effect, provides a theoretical for enterprises to establish a scientific and rational incentive system reference on. This change of perspective research governance structure to help guide enterprises to shift from the regulatory perspective governance structure to manage the effect, avoid the treatment effect only rely on the law and other hard targets internal evaluation of the enterprise, when reforming corporate governance system blindly follow Europe and other relevant laws and regulations in developed countries while ignoring the actual treatment effect resulting "acclimatized." Focus to guide reform the internal governance structure of a "compliance" to improve corporate governance performance as the goal changes.

\section{LITERATURE REVIEW}

As early as 2006, earthquake network (Stuxnet) virus invaded Iran nuclear plant, incubate for up to 5 years, and broke out in 2010. As a specially tailored for Iran's Natanz nuclear plant virus weapon, its destructive power is enormous, the consequences led to paralysis of Iran's nuclear program (Grublješič et al., 2019). In 2006, the system processor inside Syria Yin Leida back door vulnerabilities, leading to total paralysis of the radar system, Israel 18 F-16 fighter planes effortlessly gap Syria a potential nuclear facilities. Gulf War, Iraq's air defense network printer back door because of loopholes, the US military easily break. May 12, 2017, China was blackmail virus "eternal blue" attacks, basic education network a total standstill, government departments and large state-owned enterprises also are affected. Among them, China Petroleum gas station's collective "off network" can only accept cash payments. On the surface, this is just a vicious hacker attacks on together, but according to subsequent media reports, hackers steal is under the command of the US National Security Agency, "Formula One teams' arsenal. This is just leaked from the US National Security Agency attack tools, once the future send network warfare, national striker shot, hazards and the impact will expand geometrically, the normal operation of the social economy could face paralysis, the consequences could be disastrous . These events caused by fundamental reason is that these countries without their own computer hardware and software technology independent intellectual property rights, over-reliance on foreign technology. The resurgence of the US seal kill event, so China has always been aware of the market for technology, low-cost solutions to the problem with the purchase of globalization, does not work (Lin et al., 2003). No intellectual property rights, everywhere will be controlled by others. Not just the chip as the representative of the microelectronics industry, "innovation" may be referred to keep the development of China's future business students a keyword.

Schumpeter (Joseph Alois Schumpeter), published in 1912, "The Theory of Economic Development (in English)" (Theory of Economic Development), a book, the definition of Chong Hing is: Innovation is a kind of break the routine, different from the traditional mode of thinking inertia, its essence is the role of existing resources, adopt new methods or means, "create" something new. Mansfield, Rapoport, Romeo, Wagner, \& Beardsley (1977) to the relationship between technological innovation and market structure for the research perspective, the study carried out with the conclusion of Schumpeter's explanation. They will be divided into three areas of innovation in the market: technology, management and systems. Enterprises by new production processes, the introduction of the original technical rules and regulations, and management systems, access to enhance corporate value (Adams et al., 2010; Aldefer, 1972; Ameer, 2010; Andrews, 1980; Ansoff, 1965; Armanios, 2011). Therefore, we believe that innovative companies is through the original technology innovation, management and systems to enhance the performance and value of the business; and interaction as an opportunity to promote the company and the market, the market reaction to the enterprise in a timely manner, and vice versa market impact enterprise (Baron \& Kenny, 1986). 
China GEM board due to open relatively late, especially in recent years, mostly in the GEM listed companies in the early stages of the corporate life cycle, faced with high uncertainty in the new situation there is no current reference standard, thus at high risk stage (Becker, 1964). The development of innovative companies, is an important force to enhance the state-funded innovation, which gives new meaning to governance and innovative enterprises. Armanios (2011) points out, profits and other financial indicators alone may not be a comprehensive assessment of governance performance of innovative companies, the company's viability, innovation, etc. should also become an important measure of the effect of corporate governance.

By literature review, we find that the existing literature on governance performance was not clearly defined, nor does it establish a clear measure of system. Empirical research literature in most cases, financial performance, accounting indicators to measure the value of the company and other governance performance (Belloc, 2012). The measure is certainly an important dimension measure of corporate governance performance, but not a comprehensive description of the effectiveness of corporate governance, but also reduces the extension of governance performance. Corporate governance performance indicators in this study, Chinese companies listed on GEM as samples from a measure of corporate governance implementation point of behavioral effects, the establishment of management and innovation in two dimensions, contribute to a more scientific measure of corporate performance of the functions of the relevant agencies effective sex; on the one hand it is possible to deepen the theory of governance performance in science and empirical research to quantify the company, on the other hand it is also possible to provide a reference for exploring the differences and relations between management activities and results of the company's innovation in empirical research.

Based on this background, to be combined from 2019 to 2020 Chinese companies listed on GEM panel data (Panel data), with corporate governance objectives for the research perspective, combining theory study attempts in the background Chinese innovative enterprises, carried out the mechanism between exploratory research and governance structure and performance of this kind of relationship between corporate governance structure and corporate performance to make a little superficial explanation (Berle \& Means, 1991).

\section{HYPOTHESIS PUT FORWARD}

According step Wenzhong Lin et al (2004) examined the mediation effect, first of all explanatory variables are the explanatory variables affect the governance structure of governance performance assumptions. MEDIATOR but the test is divided into two paths, one is the coefficients a, b significantly when, by fractional test, $\mathrm{a}$ is a coefficient $\mathrm{a}, \mathrm{b}$ there is not a significant test for Sobel. Accordingly, in view of the present study is discussed in mediating effect is present, in order to avoid meaningless excessive repetitive description, assuming no further management structure governance performance dual path directly MEDIATOR assumptions (Blair, 1995). Assuming that the process is divided into two steps: First, the relationship between the explanatory variables and the dependent variable of the hypothesis, the second is the intervening variable is working hypothesis. In the process of development, if a company wants to maintain a better competitive position in the market, it needs to constantly adjust its product structure and carry out industrial reforms. The company must innovate continuously to ensure its invincibility in the competition. It can be said that listed companies need to use perfect corporate governance mechanism as a guarantee if they want to be able to develop steadily for a long time. The relationship between the governance structure and performance of listed companies can be studied to make good improvements in the internal operation and performance of the company and thus make the company's international competitiveness grow.

\subsection{Hypotheses Governance Structure and Performance}

Concentration of ownership and operating performance in the past for the genre ownership concentration and performance management are divided into two groups: one is Berle \& Means (1991) 
represented a significant correlation school and those who are Demsetz (1983), represented by not related to school (Boyd, 1990). In view of the latter sample selected relatively extreme, there may be errors in the measurement, therefore, the present study supports ownership concentration significantly associated with the operating performance. Within the genre change, it is divided into two linear and non-linear relationship study logic. To BaiChongEn (2005), represented by scholars believe that ownership concentration and operating performance in an inverted U-shaped relationship, but there is data in its study of the error on the measure (in 2000 China in the stock market "bull market", the stock price high, and China non-tradable shares of listed companies stock price is overvalued, and therefore in terms of its discount, but the authors did not state the reasons why the share price discount of $70 \%-80 \%$ of the theoretical and empirical evidence), a sample study of Chinese listed companies is not the GEM companies, and therefore oriented referential can learn little research. With findings and Chenfeng Bo Wang Xiaowei (2014) show that ownership concentration and lower operating performance at first, then increase, finally falling parabolic relationship. Indeed, the management of the stake as a dimension equity structure considerations understandable, but the study did not make a clear definition of the difference between this behavior equity incentive and equity properties may confuse the governance structure and behavior, and empirical test in no consideration the relationship between endogenous variables and the lagged effects, therefore, that the finding may have some errors. In view of this, we refer to Mei Feng and Sun Dandan (2014) study concluded that Chinese companies listed on GEM as small and medium enterprises in the early life cycle of its equity focus is conducive to enhancing enterprise performance, and thus established assumptions. New is to deepen and innovate by taking the original things as the basis, and then break through the parts that are not in line with the historical development. During the growth of socialist market economy in more than 20 years, it also has its own set of innovation path. In terms of the development of China's socialist market economy, it firstly broke through the planned economy and formed the idea of a planned economy as the mainstay and a market economy as a supplement. Secondly, it confirmed that the market economy is a planned and commercialized economy. Finally, it fundamentally broke the old idea of planned economy and established a socialist market economy with public ownership as the main system and multiple ownership systems co-existing.

H1: Ownership Structure and Business Performance was positively correlated.

\subsection{Board Structure and Innovation Performance}

Carpenter \& Westphal (2001) pointed out that innovation strategic choice largely depends on the level of education of the board of directors. Well-educated, with a high level of education of directors, general directors for its relatively more abundant knowledge structure, cognitive stronger; information processing capacity and risk tolerance also stronger than general director. Therefore, in the enterprise strategic choice, prefer innovation strategy. Meanwhile, Carpenter \& Westphal (2001) with the requirements of the innovation process, they believe, for the enterprise to be carried out or being carried out for technological innovation, decision-makers need to be collected in accordance with rapidly changing information, sorting, induction and extraction, further analysis, to grasp the opportunities of technological innovation, which requires internal decision-making team with a strong cognitive abilities and complex information processing and analysis capabilities. Not only that, Dalziel, Gentry \& Bowerman (2011) pointed out that higher education can provide innovative management director, accumulated knowledge assessments and other research and development projects to enable them to identify value-added innovation to the enterprise. In addition, reference can provide suggestions for the enterprise technology innovation, enterprise innovation activities contribute to sustained and effective conduct. On the other hand, relatively highly educated director director general ability to accept new things, tolerance for uncertainty are stronger Mcelroy, Seta \& Waring (2007), therefore, prefer a higher relative risk of technological innovation strategy. In summary, the Board of Directors 
by the high level of education better able to cope with the uncertainty of technological innovation process, tend to increase investment in innovation of technology companies. Based on this, to make assumptions:

H2: Board Structure and positively correlated with innovation performance.

\subsection{Hypothesized Mediating Effect of Governance Practices}

Innovative enterprises are in the early stage of the life cycle of a special class of business enterprise, due to resource scarcity and uncertainty in the external environment, in the early stages at a higher risk. Viability not only in the level of its management, but also on the strength of their own innovation. Innovative companies a competitive advantage comes from its ability to innovate itself, and one of the necessary conditions to enhance innovation capability of enterprises focused and sustained long-term commitment to innovation and resource allocation. Therefore, shareholders tolerance to continued investment in innovation, the management level of acceptance continuous innovation investment, innovation and the ability to determine the sustainability of the enterprise. If business ownership is too dispersed, with the balance of power and so does the information, management will not be subject to effective supervision, which increases the risk of self-serving decisions of management, decision-making more of its goal is the pursuit of self-interest short-term behavior, this will have a serious adverse impact on the long-term, sustained investment in innovation activities. On the other hand, excessive fragmentation of ownership, the right to travel cannot concentrate, and greatly increases the likelihood of transfer of share capital, mergers and acquisitions and even the overall situation appears. All the government management innovation will end up in the system innovation, and only through the form of system innovation results will be cured, to play the sustainable role of innovation, otherwise it will become "sport" innovation. Take our emphasis on the concept of service, if we simply talk about innovation on the concept of innovation, it can only stay on the subjective level, not easy to operate, but also unsustainable, once the results of innovation through the form of institutional innovation, the concept of innovation will be cured, it will form a long-term service momentum, such as the first-ask responsibility system, commitment system, on behalf of the system, parallel approval system, etc. From the systemic point of view, the government management system of a country or region should be a system in which not only the system subsystems are required to be complete, but also the vertical structure, horizontal structure, and formal structure of these system systems (physical system, procedural system, supervision system, evaluation system, etc.) supporting scientific and reasonable. The equity to change the situation too often, will increase the corporate decision-making, program variables, innovation activities of enterprises may be due to the lack of long-term stability of resources, policy support and stranded. In addition, dispersed ownership could lead to an imbalance of internal oversight mechanisms, breeding ground "free rider" effect, the lack of internal cohesion and dynamism, enthusiasm decreased enterprise value decline, the company fell, all these unfavorable conditions may also cause shareholders especially tall shareholder holding ratio lack of motivation to support investment in innovation activities.

Therefore, in the study of the relationship between the two, in which the process cannot be ignored, that is their own in the supervision, management and other aspects of governance behavior incentive to make. Derivation of the governance structure of the mechanism for governance performance before combination of text, we believe that the impact on the governance structure of governance performance is not a simple and straightforward, but the impact by influencing the behavior of governance and thus governance performance. Thus, according to $\mathrm{H} 1, \mathrm{H} 2$, knot SCP paradigm, mediating effect on governance practices are explanatory variables and explained variables make assumptions:

H3: Supervision behavior plays an intermediary role between Equity Structure and Operating Performance. 
H4a: Incentive Compensation behavior plays an intermediary role between the ownership structure and innovation performance.

H4b: Equity incentive behavior plays an intermediary role between the ownership structure and innovation performance.

H5: Supervision behavior acts as an intermediary between the Board Structure and Operating Performance.

H6a: Incentive Compensation behavior plays an intermediary role between the Board Structure and Innovation Performance.

H6b: Equity incentive behavior plays an intermediary role between the Board Structure and Innovation Performance.

\section{DATA COLLECTION AND VARIABLE SETTINGS}

There is no difference between the two. Corporate governance structure generally refers to corporate governance. Corporate governance, understood in a broad sense, is a science that studies the arrangement of corporate power. In a narrower sense, it is the science that resides at the level of corporate ownership and studies the delegation of authority to professional managers and the exercise of supervisory functions with respect to the performance of their duties by professional managers. First, how to ensure the return on investment of investors (shareholders), that is, to coordinate the interests of shareholders and enterprises. The second is the coordination of the relationship between various interest groups within the enterprise. This includes incentives for managers and other employees, as well as constraints on top management. The third is to improve the enterprise's own risk resistance. A reasonable corporate governance structure can effectively alleviate the conflicts of various interests and enhance the enterprise's own risk resistance. In the empirical section of this article to GEM's panel data from 2019 to 2020 Chinese listed as samples to governance as an explanatory variable, governance performance as the dependent variable, governance practices as an intermediate variable, using the R language, Eviews statistical software the mediating effect test approach, the model constructed to test, combined with Chinese enterprises listed on the GEM status quo, from the actual situation, make recommendations, provide reference to improve China GEM corporate governance.

\subsection{Governance Structure Variable}

Mei Feng and Sun Dandan (2014) view that, in order to China GEM listed companies as samples, mainly due to the ownership structure generally use equity ownership concentration and nature interpretation, while Chinese companies listed on GEM high concentration of ownership and property ownership relatively simple, so the main choice of concentration of ownership to measure ownership structure. In this paper equity ratio of the top ten shareholders of measure ownership concentration. Be paper board structure mainly from human capital, research, according to Sun Ye Shao Fang Jing and Yin Zhao days (2018), with the highest director of education mean measure of its human capital, specifically assigned as follows: Dr. 5, Master 4, undergraduate 3, vocational 2, vocational and below 1.

\subsection{Governance Behavioral Variables}

Reference herein Shleifer \& Vishny (1997), Zheng Hongliang (1998), and Qian (1995) point of view, the behavior of corporate governance and supervision is divided into two dimensions incentive to study.

The number of board meetings is an important part of the supervision measure the intensity of behavior. Kim, Burns \& Prescott (2009) believes that the Board of Directors highly participatory governance, the Board of Directors on the strategic direction and management of strategic investments to establish a comprehensive evaluation. Instead, Judge Jr \& Zeithaml (1992) believes that the board often become less involved in the management of strategic proposals "rubber stamp", director passive acceptance of the evaluation given by the management, oversight functions also irrelevant. Garg (2013) pointed out that the Board is to fulfill the functions of a variety of ways, not limited to the board of 
directors, and interact with the CEO also has a formal board meetings, as well as e-mail, telephone, personal visits and other informal manner. Therefore, due to the difficulty of collecting other variables too difficult, and therefore According to Kim, Burns \& Prescott (2009) point of view, the use of board meetings as a measure of oversight behavior. Only through continuous innovation can enterprises adapt to new opportunities in the new era, and only through innovation can enterprises produce sudden changes and can adapt to rapid changes in the market. To adapt to the new market and new business environment in the Internet era and to transform and develop, innovation is indispensable. From the macro level, innovation can be divided into basic technology-based innovation, engineering technology-based innovation, customer-centered innovation, and efficiency-driven innovation. With the popularization of Internet technology and the deepening of user-centered concept, enterprises gradually put their focus on the matter of improving efficiency, and efficiency-driven innovation, which drives the innovation reform of enterprises with efficiency, has become the focus.

Board of incentives for managers to be protected not only from the material, but also to be considered from the implicit incentive rights, status, reputation and so on. Therefore, this behavior incentive for the use of incentive pay and equity incentives two indicators to measure.

\subsection{Governance Performance Variables}

According to the definition of governance performance: governance performance is the reaction of governance for Chinese companies listed on GEM, the governance performance not only need to explain to enhance corporate value in terms of financial performance, accounting and other indicators, but also the effect on the ability to innovate interpret, and a description of governance performance measure, this study will govern the performance of Chinese companies listed on GEM's operating performance and innovation performance is divided into two dimensions were studied. By literature review, research scholars with Tobin's Q, ROE and other variables on business performance in general. But should be noted that, although Tobin's Q is often used to describe a reflection of business performance variables, scholars often used to describe the enterprise value, but is still based on the Chinese stock market is not mature enough, the GEM listed company's shares to its own characteristics (high volatility and high turnover), according to the results of research Xu Liping, Yu Xin and Chen Gong Meng (2006), the turnover is highly volatile and difficult to make Tobin's Q reflects the performance of the enterprise, therefore, we use ROE as a business performance proxy variables.

Excessive delegation of power inevitably leads to a decrease in efficiency, which will prevent the company from responding to market changes in a timely manner. Most importantly, the general meeting of shareholders will reduce the enthusiasm to control the company, and these results are likely to lead to conflicts among shareholders, which are prone to conflicts and are not conducive to the stable operation of the company. Although studies have mostly use technological innovation research and development expenses ( $R \& D$ ) to measure technological innovation, but because of the GEM listed companies to technological innovation as the goal of performance output, the use of R \& $\mathrm{D}$ such traditional accounting measure is not sufficient to measure their Innovation capacity. Thus, the number of measurements used herein patents. In China, a longer period of patent applications, in general, to obtain authorization from the patent there is generally lag about two years, the number of patents statistics of enterprises not accurately gauge their ability to innovate. So we use the annual number of patent applications as a proxy for business innovation capability of enterprises.

According to the study Wenzhong Lin et al (2004), the mediating effect of model test is a single explanatory variables, the relationship between the intermediary variables and explanatory variables, since the study involved a multi-variable, so the need for explanatory variables, intermediate variables are independent variables correlation analysis, detecting whether the principal component regression (Principle component regression, PCR), the data dimension reduction, approximated data representing analyzed by extracting data from a small number of principal components, in particular the results of Tables 2, 3 and 4. 
Table 1. Each variable name abbreviation and measurement

\begin{tabular}{|l|l|l|}
\hline \multicolumn{1}{|c|}{ Variable name } & $\begin{array}{c}\text { Variable } \\
\text { abbreviations }\end{array}$ & \multicolumn{1}{c|}{ Measurement method } \\
\hline Ownership Concentration & CR & Shareholding of the top ten shareholders and \\
\hline Board intellectual capital & BH & Mean the Board of Education \\
\hline Supervision of strength & BM & The number of meetings of the Board \\
\hline Salary incentives & EC & The top three executive pay is the natural logarithm \\
\hline Equity incentive & EI & $\begin{array}{l}\text { Dummy variable, then there is equity incentive cases take } 1,0 \\
\text { otherwise }\end{array}$ \\
\hline Roe & ROE & Net profit / total asset balance \\
\hline Innovation capacity & PA & The number of patent applications \\
\hline
\end{tabular}

Tables 2, 3 and 4 point of view, almost no correlation between the variables, and therefore can not call the shots component regression, therefore, to examine the mediating effect step by step, and thus, empirical models also need to be re-amended in accordance with the mediating effect inspection requirements, the path econometric model also needs to be designed, and after empirical testing, the need for empirical model for further amendments. Motivation mainly includes material motivation and spiritual motivation, positive motivation and negative motivation, internal motivation and external motivation, etc.

Table 2. Pearson (Pearson) correlation analysis of the explanatory variables

\begin{tabular}{|l|l|l|}
\hline & \multicolumn{1}{|c|}{ OC } & \multicolumn{1}{c|}{ BH } \\
\hline CR & 1 & \\
\hline BH & -0.1601424 & 1 \\
\hline
\end{tabular}

Table 3. Pearson (Pearson) correlation analysis of mediating variables

\begin{tabular}{|l|l|l|l|}
\hline & \multicolumn{1}{|c|}{ BM } & \multicolumn{1}{c|}{ EI } & \multicolumn{1}{c|}{ EC } \\
\hline BM & 1 & & \\
\hline EI & 0.2014009 & 1 & 1 \\
\hline EC & 0.1519912 & -0.0118683 & 1 \\
\hline
\end{tabular}

Table 4. Pearson(Pearson) correlation analysis of explained variables

\begin{tabular}{|l|l|l|}
\hline & \multicolumn{1}{|c|}{ ROE } & \multicolumn{1}{c|}{ PA } \\
\hline ROE & 1 & \\
\hline PA & 0.08752153 & 1 \\
\hline
\end{tabular}




\section{MODEL BUILDING}

By regression analysis, forecasting ownership structure (explanatory variables) and firm performance (dependent variable) relationship between the two, and in accordance with mediating effect model, the distribution of mediating effect of test management behavior.

Not necessarily based on a simple causal relationship between research experience mediating effect of model design, governance structure and performance, there may be mediating role of governance practices. Therefore, according to this study Wenzhong Lin, Zhang Lei, HAU Kit-tai and LIU Hong-yun (2004) define the mechanism of action and test mediational model, in order to develop research path. Empirical model and econometric model mediating effect of test is shown in Figure 1.

This test model is provided to perform processing center (i.e., zero mean) of all the variables (X argument, mediating variables $\mathrm{M}, \mathrm{Y}$ dependent variable), then a test equation of the regression coefficients so 1 to 3 (Wenzhong Lin et al., 2004). If the argument significantly affected by the variables (coefficients c significant), and a causal chain $\mathrm{X} \rightarrow \mathrm{M} \rightarrow \mathrm{Y}$ in any variable, when the control of its pre variables (including arguments), significantly affecting their subsequent variables may be considered mediating effect significant (Baron \& Kenny, 1986).

\section{Figure 1. Mechanism and test mediational model}

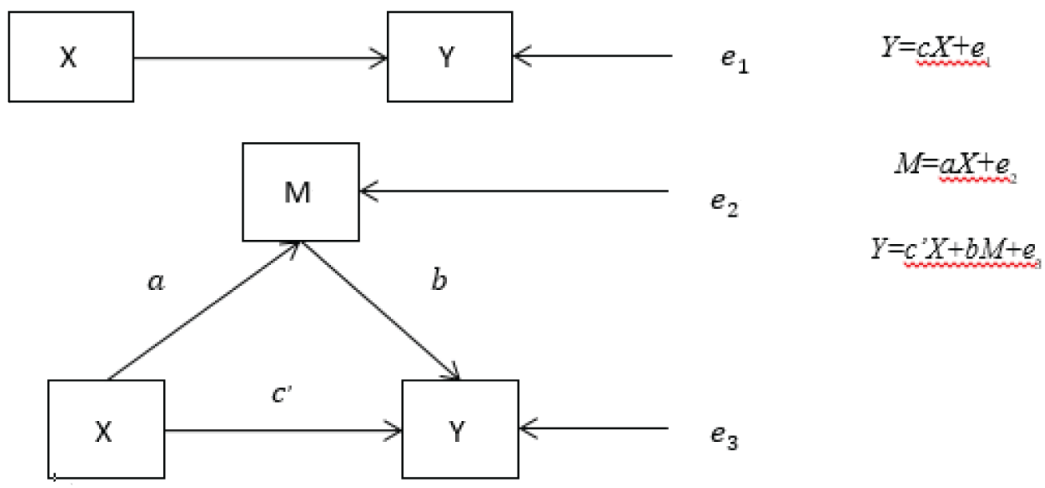

Specific steps of a three-step test:

1. Verify that the equation of regression coefficient $\mathrm{c} 1$. If not significant, indicating independent variables (explanatory variables) $\mathrm{X}$ and the dependent variable (being and explained variable) no correlation between $\mathrm{Y}$, mediating effect does not exist, stop testing; as significant, indicating $\mathrm{H} 0$ : $\mathrm{c}=$ assuming 0 is rejected to meet the mediating effect of the test conditions, the next test.

2. The test equation 2 , respectively, the equation regression coefficient a 3 , b, both as significant, the third inspection unit. As neither of significant mediating effect is not present. The at least two have a significant need for further examination Sobel discussed mediating effect.

3. The last test equation $3 \mathrm{c}$ 'regression coefficients, as no significant mediating effect described fully, partially mediating effect and vice versa, wherein the mediating effect is ab / c. Specific test path, see Figure 2.

According to Sobel, Wiley \& Sobel (1982), Sobel (1987) findings, Sobel test statistic of z, embodied as follows: 


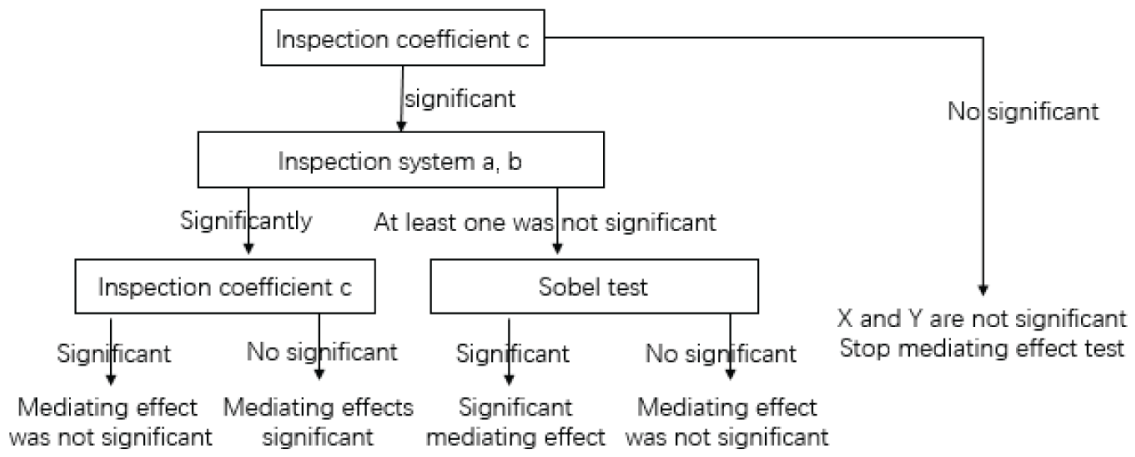

$Z=\hat{a b} / s_{a b}$

$S_{a b}=\sqrt{\hat{a}^{2} S_{b}^{2}+\hat{b}^{2} S_{a}^{2}}$

Wenzhong Lin et al. (2004) threshold value is considered Sobel z (-0.97, 0.97), but Mackinnon, Warsi \& Dwyer (2015) noted that the value of $0.97 \mathrm{~N}=0.04$ two-sided statistical probability corresponding to the 200 , but when the statistical value of less than 0.9798 th sometimes greater than 0.8797 th, determines the value corresponding to the probability of more trouble at this time to be used as $0.90 \mathrm{P}<0.05$ statistical value to be determined. Thus, this paper Mackinnon et al (2015) point of view, the threshold value is defined as Sobel z $(-0.90,0.90)$. Where, a and b are estimated a, b's, s_a, s_b a and b are the standard errors. $z$ statistic out $(0.90,0.90)$ of the segment can be considered significant mediating effect. It includes the number of invention applications, invention application rate, invention authorization rate, invention withdrawal rate and invention rejection rate. The number of invention applications is the number of invention patent applications of each unit.

From the foregoing the arguments / explanatory variables governance structure, mediating variables control the behavior of the dependent variable / is interpreted dimensions variable governance performance of the division, the governance structure is divided into the ownership structure, the Board of Directors institutions two dimensions, governance practices are divided into oversight behavior, motivation conduct two dimensions, performance management is divided into business performance, innovation performance two dimensions, and in accordance with the foregoing analysis of the governance structure of governance practices $\rightarrow \rightarrow$ governance performance mechanism of action, the study paths defined in the shareholding structure $\rightarrow \rightarrow$ monitor the behavior of operating performance, equity $\rightarrow$ behavior $\rightarrow$ incentive structures operating performance, conduct oversight board structure $\rightarrow \rightarrow$ innovation performance, the board structure $\rightarrow \rightarrow$ behavior mechanism innovation performance four research paths, and so build an empirical model variables. 
Figure 3. Empirical model of the relationship between variables

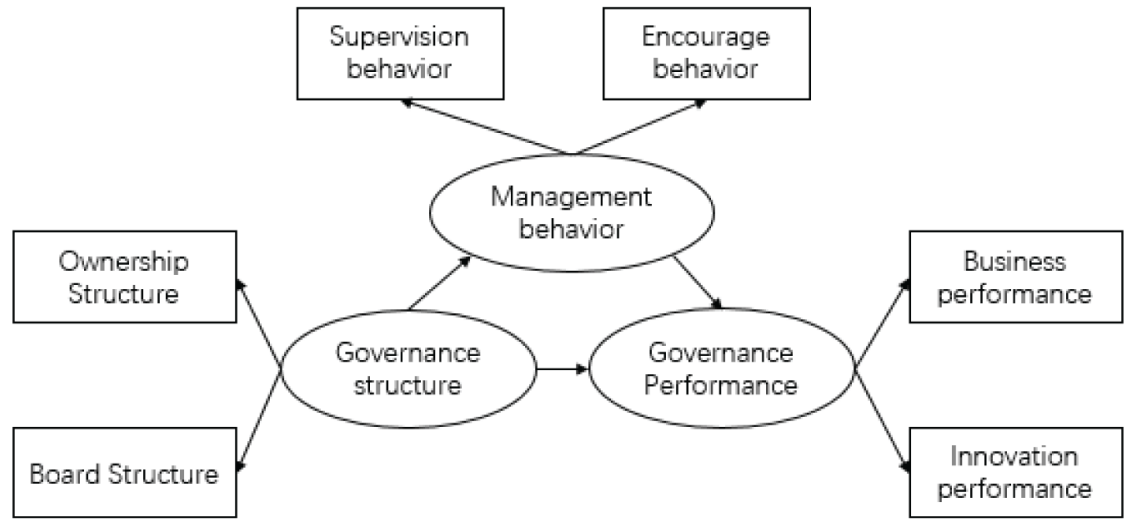

\section{MODEL CHECKING AND CONCLUSIONS}

\subsection{Select Samples and Data Sources}

By examining the relative scarcity of factors, contribution rate of production factors, asset specialization, risk bearing capacity, and superstability of the consequences of factors' behaviour, we analyse the game process and development trend of owners of human capital factors and owners of physical capital factors, and consider the influence of objective factors such as division of labour, technology, and market to analyse the change of ownership structure of enterprises. The logical reasoning is carried out.

In this study, 154 of 2010 China GEM listed companies reported in the GTA database to the original samples to the governance structure, governance practices, governance performance panel data ... 4 years, its study. Source of this paper is divided into two categories: one is the original data in the database, and the other is the data for manual cleaning after finishing the database based on research needs and circumstances. Among them, the 2010 GTA database of listed companies have released data overflow, were first compared to 153 according to the Shenzhen Stock Exchange released and the National Tai' an database, removing excess sample (the Shenzhen Stock Exchange stock code 300001-300154, where "300 060 - Suzhou permanent "missing data, the actual total of 153). Then clean the remaining data over the $\mathrm{R}$ language, removing the main variables with missing values "300010- Lanxum" "300013- Sunning Logistics", "Prudential shares 300023-" "300026- red medicine" "300059- East Fortune," "300139- Xiao Cheng Technology", "Central 300140- equipment" seven companies. The final selected 146 sample points, the time span from 2019 to 2020, get 3066 valid observations. Sample data source from listed companies recruit investment prospectus, annual report of the Shenzhen Stock Exchange website (referred to as the Shenzhen Stock Exchange, http:// www.szse.cn), GTA database.

\subsection{Governance Structure Variable Statistics}

From Table 5, the top ten shareholders of the sample mean equity ratio decreased gradually, indicating that Chinese companies listed on GEM equity dilution of efforts to gradually increase, the difference of equity has gradually expanded. 2013-2018 ownership concentration maximum and minimum gap is very obvious, and four years were lower than the average of the median, indicating the lowest part of the company's value too low, pulled down the average. Description of each business diversification in the arrangement of equity allocated more obvious. These three dimensions include both hard and soft indicators; both performance and behavioral assessments; both individual and group and 
Table 5. Descriptive statistics ownership concentration

\begin{tabular}{|l|l|l|l|l|l|l|}
\hline \multicolumn{1}{|c|}{ Year } & \multicolumn{1}{c|}{$\mathbf{N}$} & \multicolumn{1}{c|}{ Mean } & \multicolumn{1}{c|}{ Std Dev } & \multicolumn{1}{c|}{ Median } & \multicolumn{1}{c|}{ Min } & \multicolumn{1}{c|}{ Max } \\
\hline 2010 & 146 & 71.016 & 8.2335 & 73.54 & 43.37 & 90.68 \\
\hline 2011 & 146 & 67.913 & 9.1343 & 69.19 & 44.44 & 91.4 \\
\hline 2012 & 146 & 64.9925 & 9.7313 & 66.095 & 40.08 & 89.82 \\
\hline 2013 & 146 & 59.9337 & 11.2472 & 61.275 & 28.34 & 88.73 \\
\hline
\end{tabular}

organizational assessment requirements; both simple and clear to understand, and good to operate and implement; and can be applied to both managers and ordinary employees.

Xiaji Jun and Zhang Yan (2008) that, collected according to the company reports the data obtained will inevitably appear relevant variables missing, the presence of errors observed variables, cross-sectional data or mixed data may appear sequence relatedness and different error term variance, whereas endogenous panel data analysis problems can be solved with time does not change by the omitted variables produced, has certain advantages, therefore, this study used this method to estimate the parameters.

Table 6 shows that for four consecutive years, the board of directors an average of close to 5 degrees maximum, indicating master director graduate, doctoral students occupied a large proportion within the board of directors, the mean and maximum values showed an increasing trend, indicating that corporate directors intellectual capital more and more attention, efforts to introduce a high level of education directors continue to increase. However, the panel data itself can eliminate certain problems of omitted variables compared to cross-sectional data. Endogeneity cannot be tested, but can only be eliminated as much as possible in the design of the model. For example, finding exogenous policy shocks. Use instrumental variables. And the absence of one of the two conditions for instrumental variables is not tested in many articles.

\subsection{Empirical}

Table 6. Descriptive statistics of average academic qualifications of the Board

\begin{tabular}{|l|l|l|l|l|l|l|}
\hline \multicolumn{1}{|c|}{ Year } & \multicolumn{1}{c|}{$\mathbf{N}$} & \multicolumn{1}{c|}{ Mean } & \multicolumn{1}{c|}{ Std Dev } & \multicolumn{1}{c|}{ Median } & \multicolumn{1}{c|}{ Min } & \multicolumn{1}{c|}{ Max } \\
\hline 2010 & 146 & 3.5218 & 0.437 & 3.5556 & 2.375 & 4.5556 \\
\hline 2011 & 146 & 3.5489 & 0.4263 & 3.5714 & 2.3636 & 4.6 \\
\hline 2012 & 146 & 3.5749 & 0.4218 & 3.5714 & 2.3333 & 4.75 \\
\hline 2013 & 146 & 3.6017 & 0.424 & 3.6548 & 2.3 & 4.75 \\
\hline
\end{tabular}

Test results in Table 7 monitor the behavior of the mediating effect between Ownership Structure and Performance.

From Table 7 , according to the equity structure $\rightarrow$ Monitor the behavior of $\rightarrow$ Performance measurement business model:

$\mathrm{ROE}_{i, t}+2^{=\mathrm{cCR}} \mathbf{i , t ^ { + e }} 1$

$\mathrm{BM}_{\mathrm{i}, \mathrm{t}+1=\mathrm{aCR}} \mathrm{t}^{+\mathrm{e}} 2$ 
Table 7. Behavior of the mediating effect between Ownership Structure and Performance

\begin{tabular}{|l|l|l|l|l|}
\hline \multicolumn{1}{|c|}{ Value } & \multicolumn{1}{c|}{ c } & \multicolumn{1}{c|}{ b } & \multicolumn{1}{c|}{ c } \\
\hline Estimated & 0.1059 & -0.0712 & 0.0070 & 0.0011 \\
\hline Std. Error & 0.0412 & 0.0413 & 0.0042 & 0.0004 \\
\hline $\mathrm{t}$ value & 2.5685 & -1.7215 & 1.6608 & 2.6841 \\
\hline $\mathrm{P}(>|\mathrm{t}|)$ & $0.0105^{* *}$ & $0.0857^{*}$ & $0.0973^{*}$ & $0.0075^{* * *}$ \\
\hline
\end{tabular}

${ }^{* * *} p<0.01,{ }^{* *} p<0.05,{ }^{*} p<0.1$

$\mathrm{ROE}_{\mathrm{i}, \mathrm{t}+2}=\mathrm{c}^{\prime} \mathrm{CR}_{\mathrm{i}, \mathrm{t}}+\mathrm{bB}$

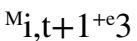

It found that the coefficient $\mathrm{c}$ significant at a confidence interval of $\mathrm{p}<0.5$, and the coefficient is positive, indicating a significant positive correlation ownership structure and operating performance. $\mathrm{H} 1$ is supported. A significant factor in the confidence interval of $\mathrm{p}<0.1$, and the coefficient is negative, indicating ownership structure and monitor the behavior of a significant negative correlation. The coefficient $b$ on the confidence interval $\mathrm{p}<0.1$ is significant, and the coefficient is positive, the coefficient $\mathrm{c}$ 'in the confidence interval $\mathrm{p}<0.01$ significant, and the coefficient is positive, indicating that monitor the behavior of between ownership structure and operating performance plays a mediating effect, $\mathrm{H} 3$ supported.

From Table 8, according to the ownership structure $\rightarrow$ behavior incentive (incentive pay) econometric model $\rightarrow$ Business Performance:

Table 8. Behavior incentive (incentive pay) test results mediating role between Equity Structure and Operating Performance

\begin{tabular}{|l|l|l|l|l|}
\hline \multicolumn{1}{|c|}{ Value } & \multicolumn{1}{c|}{$\mathbf{c}$} & \multicolumn{1}{c|}{ a } & \multicolumn{1}{c|}{ b } \\
\hline Estimated & 0.1059 & 0.0809 & 0.0133 & 0.0009 \\
\hline Std. Error & 0.0412 & 0.0413 & 0.0042 & 0.0004 \\
\hline $\mathrm{t}$ value & 2.5685 & 1.9577 & 3.1904 & 2.3221 \\
\hline $\mathrm{P}(>|\mathrm{t}|)$ & $0.0105^{* *}$ & $0.0507^{*}$ & $0.0015^{* *}$ & $0.0206^{* *}$ \\
\hline
\end{tabular}

${ }^{* * *} p<0.01,{ }^{* *} p<0.05,{ }^{*} p<0.1$

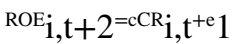

${ }^{\mathrm{EC}} \mathrm{i}, \mathrm{t}+1^{=\mathrm{aCR}} \mathrm{i}, \mathrm{t}^{+\mathrm{e}} 2$

$\mathrm{ROE}_{\mathrm{i}, \mathrm{t}+2}=\mathrm{c}^{\prime} \mathrm{CR}_{\mathrm{i}, \mathrm{t}}+\mathrm{b}$ 
It found that the coefficient $\mathrm{c}$ significant at a confidence interval of $\mathrm{p}<0.5$, and the coefficient is positive, indicating a significant positive correlation ownership structure and operating performance. H1 is supported. Equity incentives significantly reduce both explicit and implicit agency costs. These two types of agency costs play a partially mediating role in the relationship between equity incentives and firm performance, and equity incentives indirectly improve firm performance by using explicit and implicit agency costs as paths. Coefficient a significant at a confidence interval of $p<0.1$, and the coefficient is positive, indicating ownership structure and excitation behavior (pay incentive) significant negative correlation coefficient $b$ on the confidence interval $p<0.5$ is significant, and the coefficient is positive, the coefficient $\mathrm{c}$ 'on the confidence interval $\mathrm{p}<0.5$ is significant, and the coefficient is positive, indicating that the excitation behavior (excitation compensation) between the ownership structure and plays a mediating effect operating performance, H4a supported.

According to Table 9, ownership structure $\rightarrow$ Encourage behavior (equity incentives) $\rightarrow$ Performance measurement business model:

Table 9. Encourage behavior (equity incentives) test results in the intermediary between ownership knot and Business Performance

\begin{tabular}{|l|l|l|l|l|}
\hline \multicolumn{1}{|c|}{ Value } & \multicolumn{1}{c|}{$c$} & \multicolumn{1}{c|}{$a$} & \multicolumn{1}{c|}{$c^{\prime}$} \\
\hline Estimated & 0.1059 & 0.0087 & 0.0145 & 0.0107 \\
\hline Std. Error & 0.0412 & 0.0414 & 0.0042 & 0.0041 \\
\hline $\mathrm{t}$ value & 2.5685 & 0.2099 & 3.4974 & 2.5626 \\
\hline $\mathrm{P}(>|\mathrm{t}|)$ & $0.0105^{* *}$ & 0.8338 & $0.0005^{* * *}$ & $0.0106^{* *}$ \\
\hline Sobel z & 2.0702 & & \\
\hline
\end{tabular}

${ }^{* * *} p<0.01,{ }^{* *} p<0.05,{ }^{*} p<0.1$

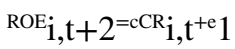

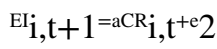

$\mathrm{ROE}_{\mathrm{i}, \mathrm{t}+2}=\mathrm{c}^{\prime} \mathrm{CR}_{\mathrm{i}, \mathrm{t}}+\mathrm{b}$

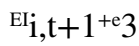

It found that the coefficient $\mathrm{c}$ significant at a confidence interval of $\mathrm{p}<0.5$, and the coefficient is positive, indicating a significant positive correlation ownership structure and operating performance. $\mathrm{H} 1$ is supported. It is not a significant factor, the coefficient $\mathrm{b}$ significant at a confidence interval $\mathrm{p}$ $<0.01$, and it is necessary to continue testing Sobel. $\mathrm{z}$ statistic $\mathrm{z}$ the Sobel test $>0.97$, the coefficient $\mathrm{c}$ 'in the confidence interval $\mathrm{p}<0.5$ is significant, and the coefficient is positive, indicating that the excitation behavior (equity incentive) between the ownership structure and operating performance plays a mediating effect, $\mathrm{H} 4 \mathrm{~b}$ give stand by. Develop new products in line with national industrial 
policy, transform backward process equipment; introduce scientific management mode; introduce counterpart talents.

According to Table 10, board structure $\rightarrow$ Monitor the behavior of $\rightarrow$ Econometric model innovation performance:

Table 10. Monitor the behavior of the test results mediating role between board structure and innovation performance

\begin{tabular}{|l|l|l|l|l|}
\hline \multicolumn{1}{|c|}{ Value } & \multicolumn{1}{c|}{ c } & \multicolumn{1}{c|}{ b } & \multicolumn{1}{c|}{ c' $^{\prime}$} \\
\hline Estimated & 0.1266 & 0.0967 & 0.0059 & 0.0027 \\
\hline Std. Error & 0.4111 & 0.0413 & 0.0042 & 0.0042 \\
\hline $\mathrm{t}$ value & 3.0780 & 2.3449 & 1.3965 & 0.6365 \\
\hline $\mathrm{P}(>|\mathrm{t}|)$ & $0.0022 * * *$ & 0.1631 & 0.5247 \\
\hline Sobel z & 1.2717 & $0.0194 * *$ & \\
\hline
\end{tabular}

${ }^{* * *} p<0.01,{ }^{* *} p<0.05,{ }^{*} p<0.1$

${ }^{\mathrm{PA}} \mathrm{i}, \mathrm{t}+2^{=\mathrm{cBH}} \mathrm{i}, \mathrm{t}^{\mathrm{e}} \mathbf{1}$

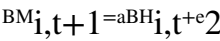

$\mathrm{PA}_{\mathrm{i}, \mathrm{t}+2}=\mathrm{c}^{\prime} \mathrm{BH}_{\mathrm{i}, \mathrm{t}}+\mathrm{bB}$

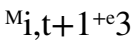

It found that the coefficient $\mathrm{c}$ significant at a confidence interval of $\mathrm{p}<0.5$, and the coefficient is positive, indicating a significant positive correlation Board Structure and innovation performance. $\mathrm{H} 2$ is supported. A significant factor in the confidence interval of $\mathrm{p}<0.05$, the coefficient $\mathrm{b}$ is not significant, it is necessary to continue testing Sobel. z Sobel test statistic of z>0.97, H5 supported.

According to Table 11, board structure $\rightarrow$ Behavior incentive (incentive pay) $\rightarrow$ Econometric model innovation performance:

Table 11. Behavior incentive (incentive pay) test results mediating role between board structure and innovation performance

\begin{tabular}{|l|l|l|l|l|}
\hline \multicolumn{1}{|c|}{ Value } & \multicolumn{1}{c|}{ c } & \multicolumn{1}{c|}{ a } & \multicolumn{1}{c|}{ b } \\
\hline Estimated & 0.1266 & 0.0398 & 0.0140 & 0.0027 \\
\hline Std. Error & 0.4111 & 0.0414 & 0.0042 & 0.0042 \\
\hline $\mathrm{t}$ value & 3.0780 & 0.9608 & 3.464 & 0.6476 \\
\hline $\mathrm{P}(>|\mathrm{t}|)$ & $0.0022^{* * *}$ & 0.3372 & $0.0009^{* * *}$ & 0.5175 \\
\hline Sobel z & 2.2655 & \multicolumn{3}{|l}{} \\
\hline
\end{tabular}

${ }^{* * *} p<0.01,{ }^{* *} p<0.05,{ }^{*} p<0.1$ 
${ }^{\mathrm{PA}} \mathrm{i}, \mathrm{t}+2={ }^{=\mathrm{BBH}} \mathrm{i}, \mathrm{t}^{+\mathrm{e}} 1$

$\mathrm{EC}_{\mathrm{i}, \mathrm{t}+1=\mathrm{aBH}} \mathrm{i, \textrm {t } ^ { + \mathrm { e } } 2}$

$\mathrm{PA}_{\mathrm{i}, \mathrm{t}+2}=\mathrm{c}^{\prime} \mathrm{BH}_{\mathrm{i}, \mathrm{t}}+\mathrm{bEC}$

$\mathrm{i}, \mathrm{t}+1^{+\mathrm{e}} 3$

It found that the coefficient $\mathrm{c}$ significant at a confidence interval of $\mathrm{p}<0.5$, and the coefficient is positive, indicating a significant positive correlation Board Structure and innovation performance. $\mathrm{H} 2$ is supported. It is not a significant factor, the coefficient $\mathrm{b}$ significant at a confidence interval $\mathrm{p}$ $<0.01$, and it is necessary to continue testing Sobel. $\mathrm{z}$ Sobel test statistic of $\mathrm{z}>0.97$, the coefficient c 'is not significant, indicating that motivate behavior (incentive pay) between the ownership structure and business performance has played a partial mediating effect, H6a supported.

According to Table 12, board structure $\rightarrow$ Encourage behavior (equity incentives) $\rightarrow$ Econometric model innovation performance:

Table 12. Motivate behavior (equity incentives) test results mediating role between board structure and innovation performance

\begin{tabular}{|l|l|l|l|l|}
\hline \multicolumn{1}{|c|}{ Value } & \multicolumn{1}{c|}{ c } & \multicolumn{1}{c|}{ a } & \multicolumn{1}{c|}{ b } \\
\hline Estimated & 0.1266 & 0.1713 & 0.0145 & 0.0008 \\
\hline Std. Error & 0.4111 & 0.0408 & 0.0042 & 0.0042 \\
\hline $\mathrm{t}$ value & 3.0780 & 4.1934 & 3.4168 & 0.1850 \\
\hline $\mathrm{P}(>|\mathrm{t}|)$ & $0.0022 * * *$ & $0.0000 * * *$ & $0.0007 * * *$ & 0.8533 \\
\hline
\end{tabular}

${ }^{* * *} p<0.01,{ }^{* *} p<0.05,{ }^{*} p<0.1$

${ }^{\mathrm{PA}} \mathbf{i}, \mathrm{t}+2^{=\mathrm{cBH}} \mathbf{i , t} \mathrm{t}^{+\mathrm{e}} \mathbf{1}$

$\mathrm{EI}_{\mathbf{i}, \mathrm{t}+1=\mathrm{aBH}} \mathbf{i , t ^ { + e } 2}$

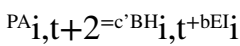

$\mathrm{t}+1^{+\mathrm{e}} 3$

It found that the coefficient $\mathrm{c}$ significant at a confidence interval of $\mathrm{p}<0.5$, and the coefficient is positive, indicating a significant positive correlation Board Structure and innovation performance. $\mathrm{H} 2$ is supported. The coefficients $\mathrm{a}, \mathrm{b}$ coefficients in the confidence interval $\mathrm{p}<0.01$ significant, 
coefficient $\mathrm{c}$ 'is not significant, indicating that the excitation behavior (excitation equity) between the ownership structure and operating performance mediating effect plays a part, $\mathrm{H} 6 \mathrm{~b}$ is supported.

\section{LACK OF RESEARCH AND POLICY RECOMMENDATIONS}

In this paper, the characteristics of GEM listed companies, on the basis of combing the governance structure of the theory, incentive-based behavior management behavior, building a governance structure, behavior spread to the mechanism model of governance performance, governance performance based on established governance practices of the multi-dimensional index system, governance structure and performance, structure and behavior, structure and thus influence by the behavior of the performance of proposed hypotheses to 2019-2020 China GEM listed companies as samples to ownership concentration, board of directors of human capital to explain variable operating performance, innovation performance is the dependent variable, supervision and behavior, encourage behavior as Mediator, the relevant testing hypotheses, verify the path Chinese companies listed on GEM governance structure influence governance performance through behavior. This article is to improve governance performance objectives of the study starting point to explore the mechanism of governance performance, to a certain extent, may have some contribution to the wealth of corporate governance, according to research findings, made the following suggestions:

1. Aspects of the GEM listing corporate governance performance measurement.

Reasonable incentive system to establish the premise and foundation when scientific evaluation of corporate governance performance. The study found that, on managerial ownership, incentive pay, it does not achieve the desired incentive effects. On the one hand it may be due to the development of enterprise incentive levels in a scientific and reasonable way for the establishment of institutional governance performance measurement, governance and thus the effect of a negative impact. On the other hand, the relationship between the GEM board of directors and managers of listed companies, unlike large mature companies, as companies in the early stages of the life cycle of its oversight functions weaker than the large mature companies, the role is to develop more reasonable incentive system. Therefore, according to their internal characteristics, scientific and rational development and implementation of incentive behavior, give full play to executive compensation and ownership incentive effects.

2. The structure of the GEM board of directors of listed companies.

To enable the board to play a "threshold" value of a positive effect, not only need to be reflected in the level of education, it should also be considered such as increasing the number of independent directors, and other aspects of the proportion of women directors, board structure optimization. Although due to time constraints, this study has not been involved in these areas, but the existing literature has demonstrated a similar point of view, businesses should not ignore these aspects. On the other hand, due to the Chinese venture capital industry is still in its infancy, companies also need to be cautious venture elections director. Finally, companies should be in the range permitted by law to extend the term of office of directors to avoid the frequent change of directors, the Board of Directors of the extent of communication between the enterprise and the degree of control of information and managers serious decline occurs. 


\section{REFERENCES}

Adams, R. B., Hermalin, B. E., \& Weisbach, M. S. (2010). The role of boards of directors in corporate governance:A conceptual framework and survey. Journal of Economic Literature, 48(1), 58-107. doi:10.1257/ jel.48.1.58

Aldefer, C. P. (1972). Existence, Relatedness, and Growth: Human Needs in Organizational Settings. Free Press.

Ameer, R. (2010). The role of institutional investors in the inventory and cash management practices of firms in Asia. Journal of Multinational Financial Management, 20(2-3), 126-143. doi:10.1016/j.mulfin.2010.07.001

Andrews, K. R. (1980). Directors' responsibility for corporate strategy. Harvard Business Review, (58), 30-42.

Ansoff, H. I. (1965). Corporate strategy: Business policy for growth and expansion. McGraw-Hill Book.

Armanios, D. (2011). Entrepreneurial firm performance: Trends, gaps, and future directions. STVP working paper. Stanford University.

Bai, , Liu, , Lu, , Song, , \& Junxi, . (2005). Empirical research governance of Chinese listed companies. Economic Research Journal, (2), 81-91.

Baron, R.M., \& Kenny, D.A. (1986). The Moderator-Mediator Variable Distinction in Social Psychological Research: Conceptual, Strategic, and Statistical Considerations. Journal of Personality and Social, 51(6), 1173-1182.

Becker, G. S. (1964). Human capital. Journal of Political Economy, 89(2), 1013-1025.

Belloc, F. (2012). Corporate governance and innovation:A survey. Journal of Economic Surveys, 26(5), 835-864. doi:10.1111/j.1467-6419.2011.00681.x

Berle, A. A., \& Means, G. C. (1991). The modern corporation and private property-2 edition. Piscataway Township. Transaction Publishers.

Blair, M. M. (1995). Ownership and control: Rethinking corporate governance for the 21st century. Brookings Institution.

Boyd, B. (1990). Corporate linkages and organizational environment: A test of the resource dependence model. Strategic Management Journal, 11(6), 419-430. doi:10.1002/smj.4250110602

Feng \& Sun. (2014). Factors affecting earnings quality of the companies listed on GEM-a perspective of corporate governance structure. Soft Science, (8), 137-140.

Grublješič, T., Coelho, P. S., \& Jaklič, J. (2019). The shift to socio-organizational drivers of business intelligence and analytics acceptance. Journal of Organizational and End User Computing, 31(2), 37-64. doi:10.4018/ JOEUC.2019040103

Hanxianglujin, H. (2012). Corporate Governance and Social Responsibility: Passive or active response embedded. Accountability in Research, (4), 58-64.

Li, C., \& Lei, S. (2001). Foreign Enterprise Incentive Theory. Economic Perspectives, 6, 61-66.

Lin, C. Q., Huang, Z., \& Sun, Y. (2003). Executives' Pay gap between corporate performance and governance structures. Economic Research Journal, (04), 31-40.

Pham, L. M. T., Tran, L. T. T., Thipwong, P., \& Huang, W. T. (2019). Dynamic Capability and Organizational Performance: Is Social Networking Site a Missing Link? Journal of Organizational and End User Computing, 31(2), 1-21. doi:10.4018/JOEUC.2019040101

4. Ping. (2006). Chinese corporate governance review and reflect on the basic theory of economists. Academic Press.

Ping \& Hai. (2012). The interaction between capital structure and corporate performance - An Empirical Research based companies listed on GEM. Accounting Research, (8), 66-71.

Qing, L. (2007). The company's performance, governance and executive compensation. Evidence from Chinese Listed Firms in Chongqing University, 13(5), 49-54. 
Shahri, A., Hosseini, M., Phalp, K., Taylor, J., \& Ali, R. (2019). How to engineer gamification: The consensus, the best practice and the grey areas. Journal of Organizational and End User Computing, 31(1), 39-60. doi:10.4018/ JOEUC.2019010103

Wei \& Xiling. (2010). Entrepreneurial team entrepreneurship difference comparison - Empirical study of the relative size of the enterprise economics and management studies. Academic Press.

Weian. (2008). Empirical research of institutional investors involved in corporate governance performance. Nankai Business Review, (1), 4-14.

Weian. (2011). The institutional basis of the GEM high-growth: Effective corporate governance. Nankai Business Review, (5), 1 .

Weian. (2013). Depend on Governance and release bonus system. Nankai Business Review, (6), 1.

Weian, Jianbo, \& Song. (2009). Comments on the theory of the root causes and context study of board governance. Nankai Business Review, (1), 130-145.

Weian \& Wang. (2007). Stakeholders Related Research and Progress On Theory of Governance. Foreign Economics and Management, 29(4), 10-17.

\section{ENDNOTES}

1. Jiang Leilei in the Anhui Open University, Anhui,230022, China who is the Corresponding Author, the email :ahddxb@126.com

Sun Wenming 1Jiang Leilei $2 *$ Dong Ke3

(1,2,3 Anhui Open University, Anhui,230022,China) 